\title{
THE ROLE OF SCIENTIFIC DISCUSSION IN THE FORMATION OF SCIENTIFIC AND CREATIVE ABILITIES AND PROFESSIONAL SKILLS
}

\section{Khosiyat Kattaqulovna Turabova}

Teacher, 52nd Secondary School Of The Shurchi District Of The Surkhandarya Region, Uzbekistan

\section{Sevara Kattaqulovna Turabova}

Doctor Of Philosophy (Phd), Termez State University Termez, Uzbekistan

\section{ABSTRACT}

This article describes the formation of the phenomenon of scientific discussion as a means of cognition and its creative interaction with the style of dialectical thinking that reflects it, based on the principles of modern logic. In particular, the importance of discussion as an important tool for the study of the laws of scientific development, one of the main ways of shaping innovative thinking.

KEYWORDS:- Debate, discussion, science, truth, evidence, reasoning, innovation.

\section{INTRODUCTION}

Achieving free thinking and independent decision-making in different situations is an important tool for young people around the world to develop self-awareness, self-respect, and successful socialization. Accordingly, the ongoing reforms in the education system in Uzbekistan have also raised the issue of improving the quality of education, in response to which "legal guarantees and mechanisms for the functioning and development of the education system in the country have been improved" $[1 ; 2]$. In particular, as a result of the effective use of modern educational technologies in the practice of higher education today, the traditional education system has been forced to modify its content. One of such modified educational technologies is the introduction of innovative mechanisms for the development of argumentative competence.Because learning the theory and practice of argumentation is the fastest and most effective way to develop a culture of logical thinking. After all, argumentative competence is the most important factor in shaping the personality of a future specialist and his success in professional activity.

Discussion as one of the special manifestations of argumentation is its most serious and active 
CURRENT RESEARCH JOURNAL OF PEDAGOGICS 2(6): 167-170, June

2021 DOI: https://doi.org/10.37547/pedagogics-crjp-02-06-31

ISSN 2767-3278

(C)2021 Master Journals

\section{Crossref do) 81 Google}

Accepted 25th June, 2021 \& Published 30 $0^{\text {th }}$ June, 2021

form. In the discussion, a clear and understandable expression of problem solving is polished, the moment of subjectivity is reduced to a certain degree, the beliefs of a person or a group are supported and have a certain power only if they are justified. Scientific discussion is a very effective tool of creative research in times of serious problematic situations in science, especially when complex and even dramatic problems arise in the field of science. It is in such a place that many alternative scientific hypotheses and theories usually emerge, and as a result, knowledge takes the form of a controversial process. In particular, in the process of scientific knowledge through discussion, a research method is implemented in the form of creating models that can give a lot of answers to the question and approbating them in cases where it is not possible to get a definite answer immediately. As a result, the research function of discussion is realized in the development of science in the form described above. It should be noted that the effectiveness of the discussion is reflected in the fact that it is possible to approach the problem from different points of view, to maximize the scientific potential of many scientists, to generalize some views or to move away from the limitations.

\section{Material and Methods}

Discussion (Latin discussio - examination, research) - "free public discussion, debate in the press or scientific meetings to properly address an issue" [2; 198]. "Debate as a special form of argumentation is its most serious and sharp form" [3; 443]. Discussion is a collective type of debate in which the purpose of the debate is to identify and compare different points of view and to find the right solution to the dispute as a result of finding an opinion that is close to the truth.G. I. Ruzavin believes that discussion differs from other specific forms of debate, especially polemics, in its argumentation, purposefulness, and the means it uses. [4; 124 At this point, if we distinguish between debate and polemics, the proponents of opposing views in polemics do not set themselves the goal of reaching an agreement. On the contrary, the main efforts of the opposing parties will be aimed at confirming their positions on controversial issues and refuting the views of their opponents. The discussion expresses the collective nature of creative cognitive activity. It serves as a means of communicating with members of a particular scientific community as an effective means of communication. With such communication, it will be possible to ensure the diversity of research, critically evaluate the results obtained, comprehensively examine and develop scientific hypotheses and theories.

The importance of discussion as an important tool for the study of the laws of scientific development, one of the main ways of forming innovative thinking, I. Sidorova also commented: "The discussion allows to solve scientific problems by involving scientists from different positions and approaches around a common problem, which increases the objectivity of scientific research, comprehensive examination of the results obtained and the hypotheses included in the discussion leads to the active development of theories "[5; 46]. Naturally, the objectivity of the discussions is also determined by the existence of contradictory features, relationships, which are inherent in the objects, events and processes under study. The contradictory features inherent in them from the very beginning lead to the emergence of conflicting opinions, hypotheses, theories.

Scientific discussions are used to achieve a variety of goals, including: identifying and posing a problem, finding a solution, evaluating an advanced point of view, determining their level 
CURRENT RESEARCH JOURNAL OF PEDAGOGICS 2(6): 167-170, June

2021 DOI: https://doi.org/10.37547/pedagogics-crjp-02-06-31

ISSN 2767-3278

(C)2021 Master Journals

\section{Crossref do) 81 Google}

Accepted 25th June, 2021 \& Published 30 ${ }^{\text {th }}$ June, 2021

of truth, verifying the logical correctness of facts and reasoning, discovering new aspects of a problem, and so on. With similar goals in mind, it is necessary to point out a number of functions of scientific discussion, as these functions characterize discussion as a method of a progressive process, albeit a gradual, complex, contradictory one, through the collective action of knowing the truth.

\section{They are as follows:}

1) Generative function (promotion of different views on the studied problems);

2) Selective function (selection of perspectives or more plausible perspectives);

3) Integrative function (synthesis of positive elements of the views under discussion and related research directions);

4) Correction function (identification and correction of stated opinions, concepts and facts);

5) The constitutional function (resolving the issue of acceptance or rejection of the views discussed).

Scientific discussion is a multifaceted and meaningful process as a complex social and psychological phenomenon. Researchers of this phenomenon usually focus on features that allow the mechanism of discussion to be determined. Its mechanism includes the following components:

- Identify the causes of disagreements, group the views of the parties (partners);

- Determine the level of differences in views, analyze the causes of incorrect positions, develop a common constructive position and establish the truth.

A number of general rules will need to be followed in order for the discussion to become a method of in-depth study of the issues under discussion, a way of thinking that progresses. The following should be taken into account:

- $\quad$ Not to avoid alternative views;

- Be able to see the object in the unity of opposites;

- Keep in mind that the views expressed are incomplete and relative;

- To try to preserve the existing truth in them, without recklessly destroying all the views of the opponent.

There are also special requirements for the organization and conduct of scientific discussions. For example, in order for a discussion to be positive, it is necessary to set at least the right goal, clearly define the subject of the discussion, be competent in the topics discussed, and have the ability to communicate.

\section{Discussion}

The main task of the discussion is to seek the truth through the struggle of ideas, the conflict of opposing views, the identification and elimination of errors, the establishment of mutual understanding. This is why the discussion is valuable for theory and practice. Only for this purpose does it benefit. But there are many examples in the history of science where ideological and political factors have had a very strong influence on the logical content and effectiveness of debates. Special attention should be paid to their ethical aspect. It is these factors and guidelines that have led to the emergence of the so-called "devil" in science, the collapse of scientific schools and traditions, the moral depression and deception of young people working in science, the tragic breakdown of the fate of true scientists. Such events can be cited as an example of the triumph of evil over truth, evil over good, and indifference to justice in Soviet biology in the 1930s and 1950s of the 20th century. Lusenko's agrobiology was accepted as 
CURRENT RESEARCH JOURNAL OF PEDAGOGICS 2(6): 167-170, June

2021 DOI: https://doi.org/10.37547/pedagogics-crjp-02-06-31

ISSN 2767-3278

(C)2021 Master Journals

Crossref dof 81 Google

Accepted 25th June, 2021 \& Published 30 ${ }^{\text {th }}$ June, 2021

a "folk science" and genetics as a "bourgeois" science. Historical fact has once again proved that the flourishing of irrationalism can lead to dangerous social consequences, such as the denial of scientific understanding of the world, the neglect of moral values.

\section{Conclusion}

In general, it can be noted that the importance of discussions, especially polemics, in modern social life is growing. It is very important to study them, because it has an objective impact on the formation and development of creative abilities and professional skills, the ability to take a firm and constructive approach to the opponent's point of view, the ability to promote and defend their personal opinions.

\section{REFERENCES}

1. Ўзбекистон Республикасининг «Таълим тўғрисидаги қонуни" 23.09.2020 й. N ЎРҚ-637.

2. Ўзбек тилининг изохли луғати. - Т.: "Ўзбекистон миллий энциклопедияси", 2006. - Б. 198.

3. Kattakulovna, T. S. (2020). The Importance Of The Discussion Method In The Development of Argumentative Competence In Students. The American Journal of Social Science and Education Innovations, 2(09), P: 443

4. Рузавин Г. И. Логика и аргументация: Учебн. пособие для вузов. - М.: “Культура и спорт", ЮНИТИ, 1997. - С. 124. Поварнин С.И. Искусство спора: О теории и практике спора. - М., 1993. (Воспроизведено по 2-му изд. Петроград., 1923). Гл.Х. - С. 42.

5. Сидорова И. М. Научная дискуссия как объект философского исследования: автореферат диссертации на соиск. уч. степени доктора философских наук. M.: 1999. - C. 46.

6. Kattakulovna, T. S. (2020). The creative interrelation of scientific debate with social life, the political situation and the dialectical way of thinking that reflects them. ACADEMICIA: An International Multidisciplinary Research Journal, 10(5), 1093-1098.

7. Turabova, S. K. (2021). Socio-Historical and Logical-Epistemological foundations of the development of the art of dispute. ASIAN JOURNAL OF MULTIDIMENSIONAL RESEARCH, 10(5), 58-61.

8. Turabova, S. K. (2021). The relationship between the development of innovative thinking and argumentative competence. ACADEMICIA: An International Multidisciplinary Research Journal, 11(5), 297-300. 